\title{
Industrialisation as a Vehicle for Uganda to Achieve a 1st World Economy by 2040: A Review of Uganda's Industrialisation Efforts
}

\author{
Abraham J. B. Muwanguzi*, Patrick Olowo, Asuman Guloba, Joseph Muvawala \\ National Planning Authority, Kampala, Uganda \\ Email: ^abraham@npa.ug, *ajbm@kth.se
}

How to cite this paper: Muwanguzi, A.J.B., Olowo, P., Guloba, A. and Muvawala, J. (2018) Industrialisation as a Vehicle for Uganda to Achieve a 1st World Economy by 2040: A Review of Uganda's Industrialisation Efforts. American Journal of Industrial and Business Management, 8, 496-513. https://doi.org/10.4236/ajibm.2018.83033

Received: January 17, 2018

Accepted: March 11, 2018

Published: March 14, 2018

Copyright $\odot 2018$ by authors and Scientific Research Publishing Inc. This work is licensed under the Creative Commons Attribution International License (CC BY 4.0).

http://creativecommons.org/licenses/by/4.0/

(c) (i) Open Access

\begin{abstract}
Uganda aspires to become "a transformed society from a peasant to a modern and prosperous country within 30 years". This aspiration and the targeted steps to be taken to achieve it are laid down in a document titled Uganda Vision 2040. Industrialisation is considered to be one of the avenues to use to achieve this Vision, despite the fact that the country has made a number of efforts to promote industrialisation in the past, which have not yielded positive results. Reviewed here are the efforts that have been made to this regard since its independence and short falls highlighted. These efforts are compared with the East Asian countries' efforts towards industrialisation to note what policy makers and investors can do better in order to have industrialisation work for a country like Uganda. The comparison is based on the fact that these countries were at almost the same economic level of development in the 1960s and therefore there is a need to learn lessons of what was done differently. The country needs to develop a stepwise approach to industrialisation that can guide all efforts towards a common agenda.
\end{abstract}

\section{Keywords}

Industrialisation, Uganda Vision 2040, Manufacturing, GDP, Economic Development

\section{Introduction}

Industrialisation is where a country moves from an economy dominated by agricultural output and employment to one dominated by manufacturing [1]. It often times involves establishment of factories that turn raw materials into products. In some of the existing developed economies of North America and 
some countries in Europe like Britain, Germany, Belgium and France, this process took place between the mid- $18^{\text {th }}$ to early $19^{\text {th }}$ century. Industrialisation requires a strong development-oriented state with a long term vision of structural transformation, a highly committed political leadership, and effective transformative institutions [2]. Most of the developing countries have not yet gone through this process and are yet to realise its benefits as they work towards achieving developed economies through industrialisation.

Uganda's Vision 2040 [3] aims at making the country a transformed society from a peasant to a modern and prosperous country within 30 years. Uganda's Vision of achieving faster socio-economic transformation is planned to be dependent on her capacity to strengthen the fundamentals for harnessing the identified opportunities [3]. Among the identified nine (9) opportunities to drive the country towards Vision 2040 is industrialisation.

Vision 2040 states that review of the development paths of developed and emerging economies shows that, except for a few oil-exporting countries, there is a strong positive correlation between industrialisation and rapid development. A strong and competitive industrial base is important to create employment, advance technology and create a resilient economy. Industrialisation also offers more export earnings, wider tax base, increased purchasing power, increased integration with agriculture, product diversification, greater efficiency, and technical modernisation and higher productivity throughout the whole economy [4].

Furthermore, the second National Development Plan, NDPII [5] states that, "The goal of this plan is to attain middle income status by 2020 through strengthening the country's competitiveness for sustainable wealth creation, employment and inclusive growth. Government shall pursue a private sector-led, export oriented, quasi-market approach, fast tracking infrastructure, industrialisation and skills development strategies in order to achieve the objectives and targets for the 5 years", [5]. The NDPII thus looks at industrialisation as one of the key avenues to move the country towards middle income status by 2020 .

Since independence, Uganda has made efforts of capitalising on industrialisation to propel the economy to middle income status and eventually to a first world economy. According to a UNIDO report 2007, Uganda was among the few African countries that had a thriving industrial sector prior to independence. There were small and medium, as well as large-scale industries, and their development was boosted with the establishment of the Uganda Development Corporation (UDC) in 1952. UDC was charged with the responsibility of promoting the establishment of industries, including joint ventures, negotiating finance and attracting direct foreign investment, as well as promoting the establishment of industrial research institutions and related support services (UNIDO, 2007).

The report notes however that most of the established industries produced consumer goods and thus failed to create the necessary meaningful forward and backward linkages with other sectors of the economy and more so the agricultural 
sector, which employed the biggest percentage of the population. Furthermore, the industries relied heavily on foreign raw materials and technology and did not alleviate the unemployment problem. Over the years, the industries failed to create the desired impetus for economic take off for national development.

With the stabilisation of the political environment in the 1990s, the government put in place a number of measures to boost the industrialisation drive. These included; the Industrialisation Policy and Framework (1994-1999), development of industry and industrial support institutions like Uganda National Bureau of Standards, Uganda Industrial Research Institute, Uganda National Council for Science and Technology, Uganda Investment Authority, among others. These measures and institutional capacity building paid off such that between 1992 and 1998 annual production grew from 11.8\% to 17\%, industrial GDP contribution grew from $10 \%$ to $20 \%$ and the number of industrial establishments increased from 1320 to 11,968 (UNIDO, 2007).

To capitalise on the achievements, these measures were followed with other policies in the 2000s; Medium Term Competitiveness Strategy for the Private Sector (MTCS)-2000-2005, 2005-2009, Poverty Eradication Action Plan (PEAP) -2004-2008, the National Industrial Policy-2008-2018, and the National Industrial Sector Strategic Plan 2010/11-2014/15.

The interventions used to boost industrial development before 2000 saw industry contribution to GDP grow from 10\% between 1980 and 1990 to $20 \%$ between 1990 and 2000 (UNIDO Report, 2007). However, interventions applied thereafter to boost industrial development did not register as much success as industrial contribution to GDP in the years 2000-2010 oscillated between 22\% 24\% (UBOS, 2010). According to Bevan, et al., 2003, this level of industrial contribution to GDP is below the targeted mark of $35 \%$ for countries aiming to achieve middle-income status. It can be noted that Uganda's industrial growth somehow stagnated over the last 15 years with its contribution to GDP currently standing at $20.4 \%$ [6]. This trend may have been due to a lack of an integrated plan that integrates the efforts of all sectors towards industrialisations and build on the gained advantages prior to 2000, and provide a sequenced path for industrialisation of the country.

As Uganda is working towards becoming a developed economy by 2040 and looking at industrialisation as one of the avenues to achieve this, this paper reviews the industrialisation efforts that have been made before, comparing these with the progress made by the east Asian countries and drawing lessons to aid the country make the right decision to realise the benefits of industrialisation.

\section{Uganda's Industrial Sector}

Uganda's industrial sector comprises mainly of manufacturing, mining and quarrying, construction, and utilities (electricity and water supply) sub-sectors, whose industries are categorized into formal and informal.

The manufacturing sub-sector is composed of food processing, manufacture 
of beverages and tobacco, textiles clothing and footwear, paper and printing, chemicals, petroleum and other chemical products, non-metallic minerals, basic metals and metal products among others. Of these, food processing, beverages and tobacco industry, saw milling, paper and printing, bricks and cement, steel and metal products, and textile clothing and footwear industry, comprise the biggest share [7].

The mining activities include mining of iron ores and non-ferrous metals, quarrying of stones, sand and clay as well as activities such as extraction of salt. The construction sub-sector includes general construction and refurbishment of structures, civil engineering works, plumbing, installations, plastering and glazing, among others.

Currently the industrial sector's contribution to GDP is $19.8 \%$; with mining and quarrying contributing $0.7 \%$, manufacturing $9.2 \%$, electricity $0.8 \%$, water $1.7 \%$ and construction 7.4\% [8]. As noted earlier, according to Bevan, et al., 2003 [9], this level of industrial contribution to GDP is below the targeted mark of $35 \%$ for countries aiming to achieve middle-income status. The services sector makes the biggest contribution to GDP, standing at $47.8 \%$, with agriculture taking the second place at $24 \%$, Figure 1.

It can be observed that the industrial sector contribution to GDP remained stable around $15 \%$ in the 1960 s and early 1970 s before sharply falling to its lowest of 5\% from around 1975 to 1980. Significant increases were realised between the years 1980 to 1985 from about 5\% to $15 \%$. There was also significant growth from 1994 to 2001, with industry contribution to GDP rising from around 14\% to $23 \%$. Having made its biggest contribution to GDP of $27 \%$ in 2008 , the sector's contribution thereafter fell to around $20 \%$ since 2010. Industrial contribution to

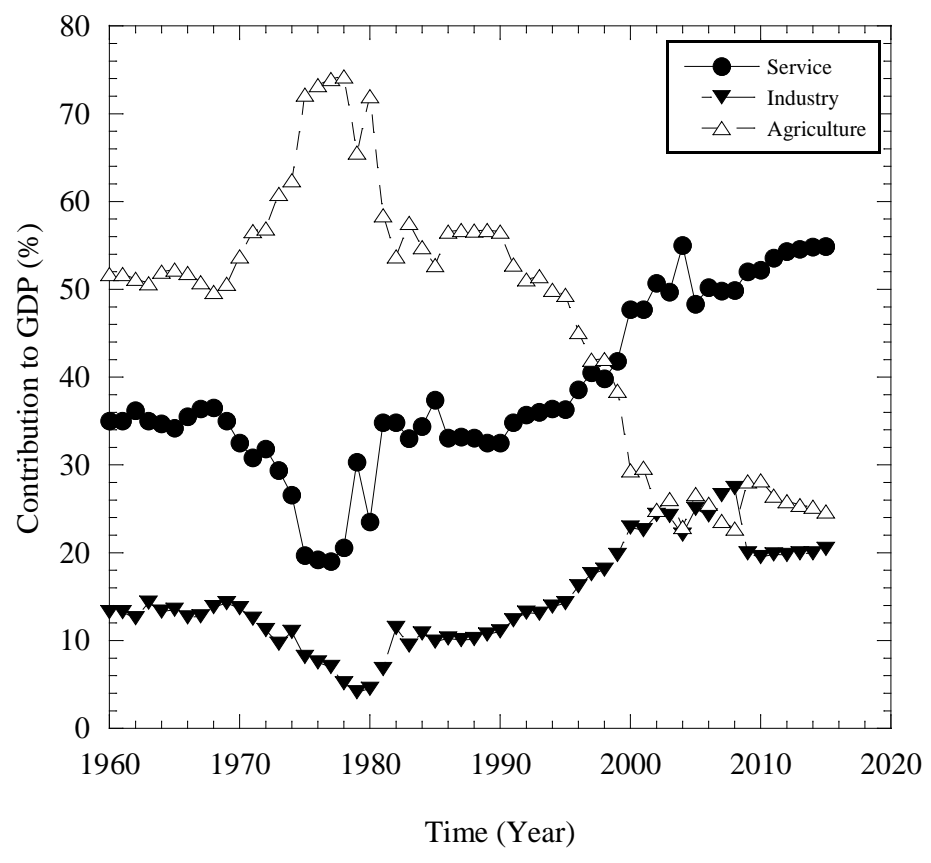

Figure 1. Uganda-contribution to GDP by the major sectors [6]. 
GDP has stagnated around 20\% since 2010.

From 1985 to 1990 , industrial contribution to GDP remained constant at $12 \%$ and increased to $13 \%$ from 1990 to 1994 . It can be noted that there was no growth in the sector over a period of 10 years. This could be explained by the effects of the impact of the political instability that the country experienced in the 1980s. The growth in industry from 1994 to 2001 can be explained by the extensive efforts the government put in to revive the sector as earlier highlighted. In this period, the industrial sector grew at an average rate of $11.5 \%$ per year.

However, the interventions that have been employed by government to boost the sector since 2001 to date have not registered as much impact on the sector as those employed between 1990 and 2001. The average industrial growth between 2002 and 2015 has been $8 \%$.

It can be noted from Figure 1 that the service sector contribution to GDP has been steadily increasing since 1980 from $23 \%$ to currently $51 \%$. On the other hand, agriculture's contribution to GDP has fallen from $72 \%$ to $22 \%$ in the same period, yet agriculture employs about $70 \%$ of the population. However, the service sector, which now makes the biggest contribution to GDP, employs highly skilled labour force; it currently employs $24 \%$ of the population [9].

Jobs are essential for Uganda's development because they determine the living standards of individuals and households [10]. The industrial sector employs about only $8 \%$ of the population and yet a well-developed industrial sector has a big multiplier effect on the other sectors and a bigger potential for job creation and economic development. There is need therefore to develop a mechanism of boosting it.

\section{Industry Subsector Contributions to GDP}

The GDP contributions of the major subsectors that make up the industrial sector in Uganda are as highlighted in Figure 2.

From the available data, it can be noted from Figure 2 that the construction subsector was leading the industrialisation drive since 2001. The major contribution of the industrial sector to GDP was thus coming from the construction subsector. According to Sarah Ssewanyana et al. [9], economic growth from 1986 to 2009 averaged around $7.7 \%$ and this was mainly driven by post war recovery and reconstruction. This therefore explains the major contribution of the construction subsector to industrial development.

The slowdown in industrial development in the country that was observed starting from the late 2000s to date may be attributed to a number of factors among which is the changed priorities and demands of the government and economy respectively. This thus led to the slowdown of the construction subsector and eventually industrial contribution to GDP. Probably the principles behind the policies that were applied in the 1990s to boost economic development that focused majorly on reconstruction have not been modified much beyond 2000 to now focus on driving industrialisation through boosting manufacturing. 


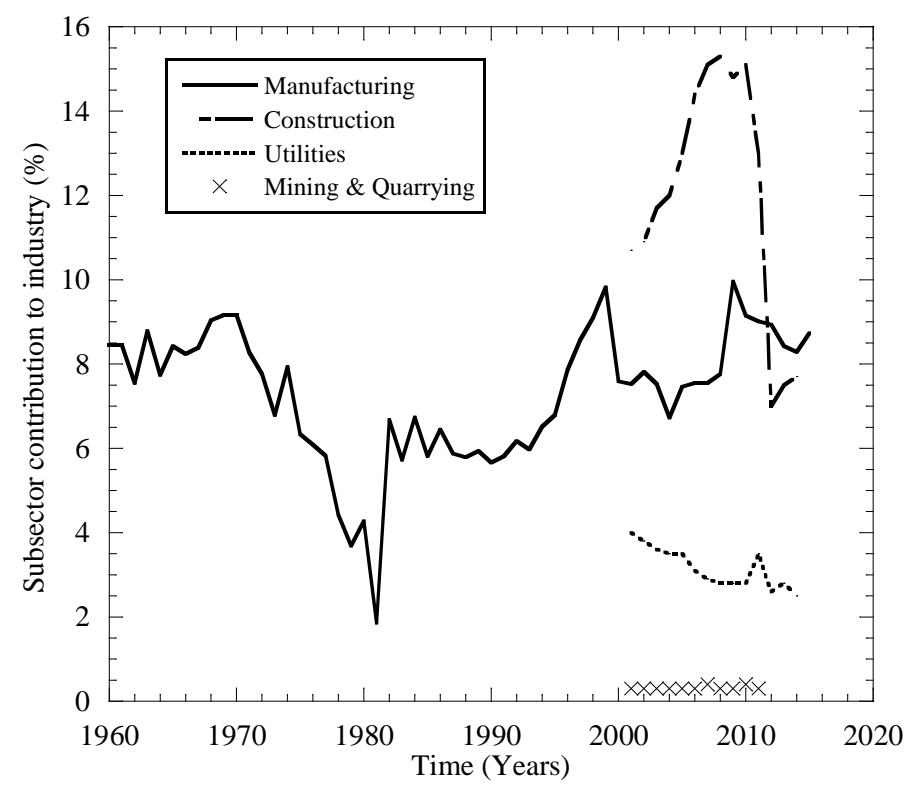

Figure 2. Uganda-subsector contributions to the industrial sector [6].

The manufacturing subsector has a high potential for the following: enhanced economies of scale and factor productivity due to technological upgrade; deeper, more dynamic and stronger forward and backward linkages not only within the sector itself (upstream and downstream activities), but also with other sectors; and greater diversification into a variety of economic activities [11]. All these factors create opportunities for employment creation and income generation. Furthermore, Uganda is endowed with a number of rich natural resources and these offer many downstream manufacturing opportunities, which present a number of employment opportunities once exploited and industrialisation is the means through which these can be unlocked and benefits realised.

Therefore, there is a need to develop a clear strategy, to guide all players on the path to take as the country works towards achieving Vision 2040.

\section{Comparison with East Asian Countries}

On a number of occasions, Uganda's level of economic development was compared to that of the East Asian countries like Singapore, Malaysia and South Korea and expected to be at this level. This has been the case because these countries were considered to be at almost the same level of economic development in the 1960s. The per capita income of these countries were in the range of USD 130 and 400 [12] in the 1970s and therefore the expectation is that they should at least be in similar ranges 40 years down the road. Figure 3 highlights the trend of growth of the GDPs of the four countries.

It can be observed from Figure 3 that the GDP of Malaysia, Singapore and South Korea tremendously increased over the time period, while that of Uganda did not make significant improvements. The trend of growth exhibited by the four countries is completely different. Twenty years down the road after 1960, in 
1980, the GDPs of Uganda, Singapore, Malaysia and South Korea were USD 1, 11, 24 and 67 billion respectively. Currently, the GDP of the three countries are USD 26, 292, 296 and 1377 billion respectively.

The GDP per capita for the four countries over the time period is also given in Figure 4.

Though the GDPs of Singapore and Malaysia are at the same level, the small

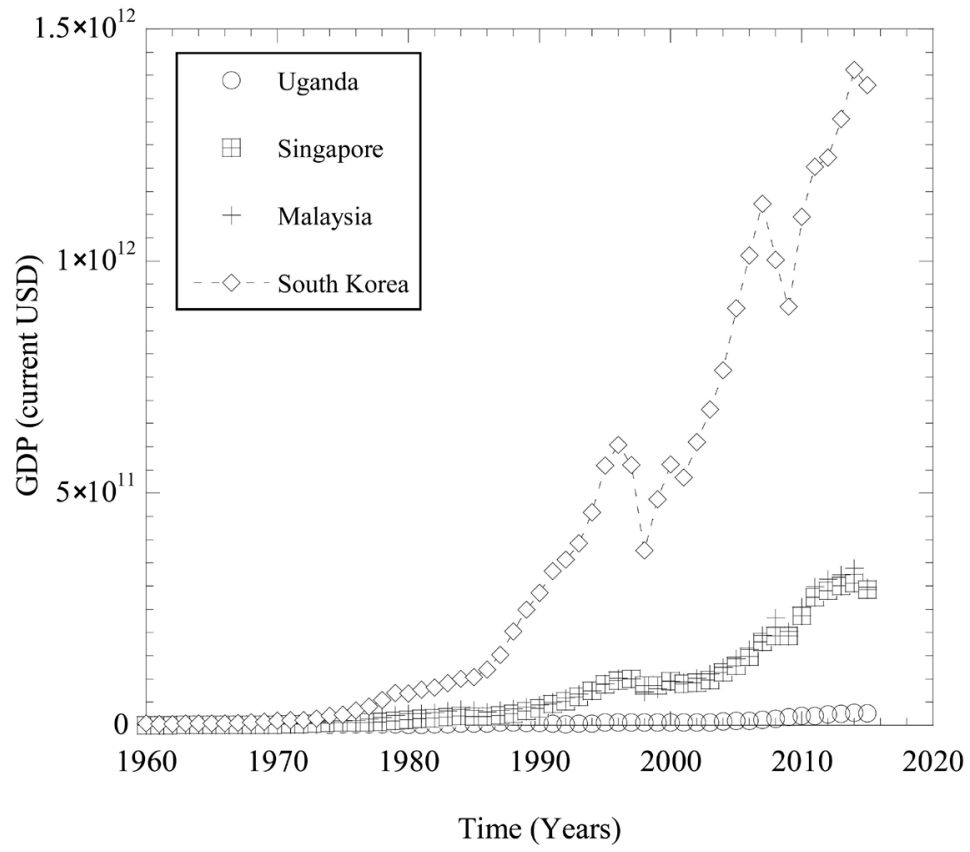

Figure 3. Gross domestic product for Uganda, Singapore, Malaysia and south Korea from 1960 to date [6].

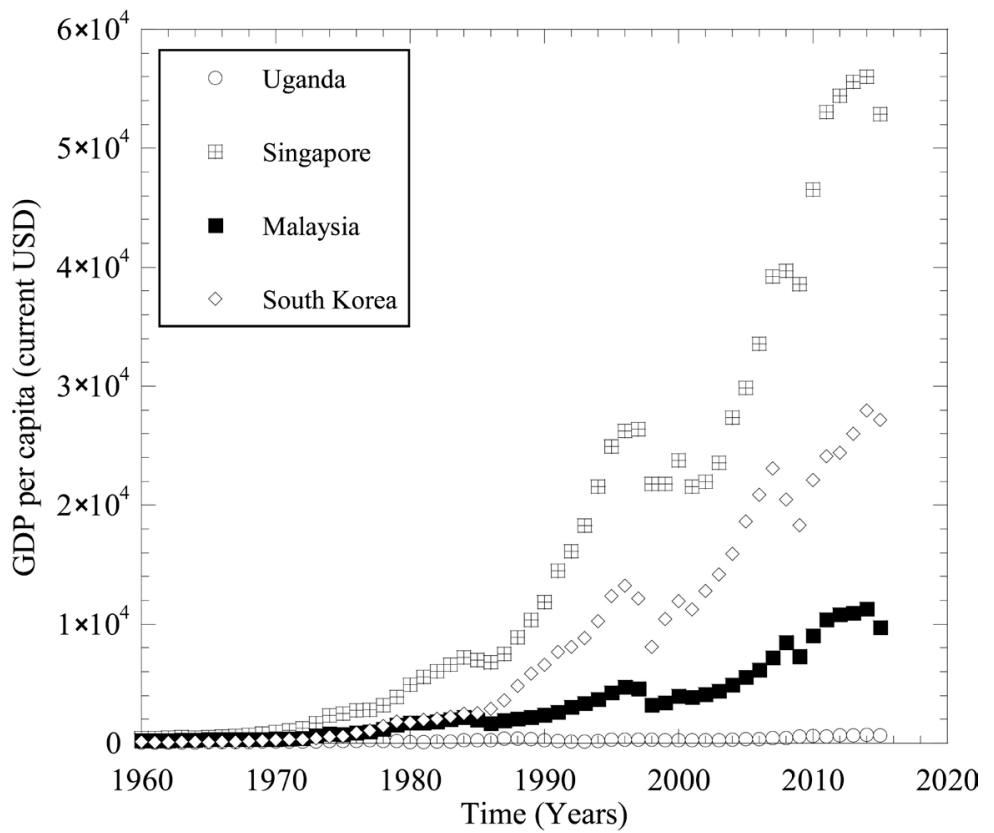

Figure 4. Gross domestic product per capita for Uganda, Singapore, Malaysia and South Korea from 1960 to date [6]. 
population size and land mass of Singapore allows its citizens to have a higher standard of living, which is even better than that of South Korea. The growth in population numbers of the four countries together with the GDP per capita growth over the years are given in Table 1.

Uganda's slow pace in economic development is partly explained by the political instabilities that the country experienced between 1966 and 1986, yet the East Asian countries, to some extent, did not experience such instabilities. This accounts for 20 years of destruction of infrastructure and systems in Uganda that would have delivered on the desired inputs to economic development. If these 20 years are offset from Uganda and the yard stick starts at probably 1990, it implies that 20 years down the road (2010) the nation's economic development should at least be at $75 \%$ the level (given that they were not at the same level of development) where the East Asian countries were in 1980, especially with Malaysia, which has similar characteristics to Uganda. However, the case presented is very different.

This may imply that even if Uganda had not experienced political instability over the 20-year period, it might not have been as developed as the East Asian economies (or even half way their current GDP). This therefore may point to the strategies that have been drafted by the various governments as far as driving Uganda's economy to a developed status is concerned. There is therefore a great need to examine the strategies taken by Uganda to boost economic development, with lessons from those steps taken by the East Asian countries as the country looks at paving a way to achieving Vision 2040.

\section{Lessons from the South Asian Countries}

Analysis of the development paths of the East Asian countries can be made and some lessons drawn on how to drive Uganda's economy to middle income status especially through industrialisation. From Table 1, it can be noted that in terms of economic activity, size of the country and population, Uganda can relate to South Korea and more closely to Malaysia. Nonetheless, Singapore can still offer lessons that can be used to draw useful practices and policies to drive Uganda's economic development.

From Figure 5(a), for the case of Singapore, it can be observed that, just like

Table 1. Statistics for Uganda, Singapore, Malaysia and South Korea [6].

\begin{tabular}{ccccccccccc}
\hline & \multicolumn{3}{c}{$\begin{array}{c}\text { GDP per capita } \\
\text { (Current USD) }\end{array}$} & & & \multicolumn{2}{c}{$\begin{array}{c}\text { Population } \\
\text { (million) }\end{array}$} & $\begin{array}{c}\text { Land area } \\
\text { (sq. km) }\end{array}$ \\
\hline & 1960 & 1980 & 2000 & 2015 & 1960 & 1980 & 2000 & 2015 & \\
Uganda & 62 & 99 & 260 & 675 & 6.7 & 12.5 & 23.7 & 39.0 & 199,810 \\
Singapore & 427 & 4927 & 23,792 & 52,888 & 1.6 & 2.4 & 4.0 & 5.5 & 670 \\
Malaysia & 234 & 1770 & 4004 & 9766 & 8.2 & 13.8 & 23.4 & 30.3 & 328,550 \\
South Korea & 155 & 1778 & 11,947 & 27,221 & 25 & 38 & 47 & 50 & 96,460
\end{tabular}




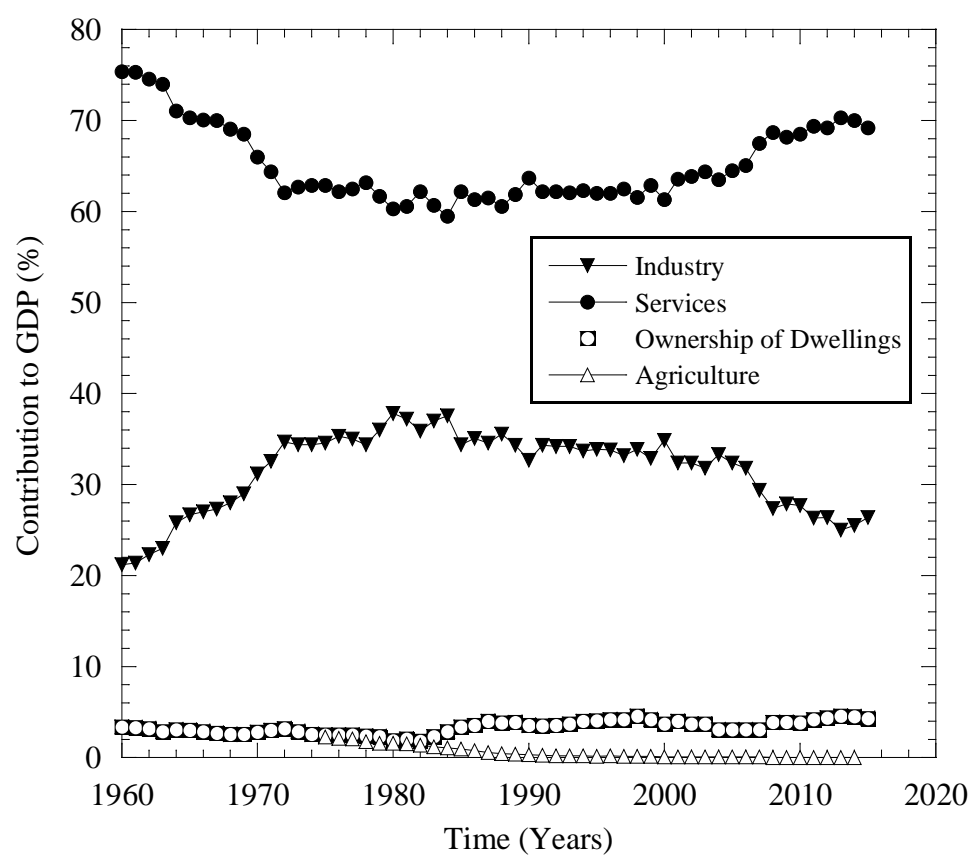

(a)

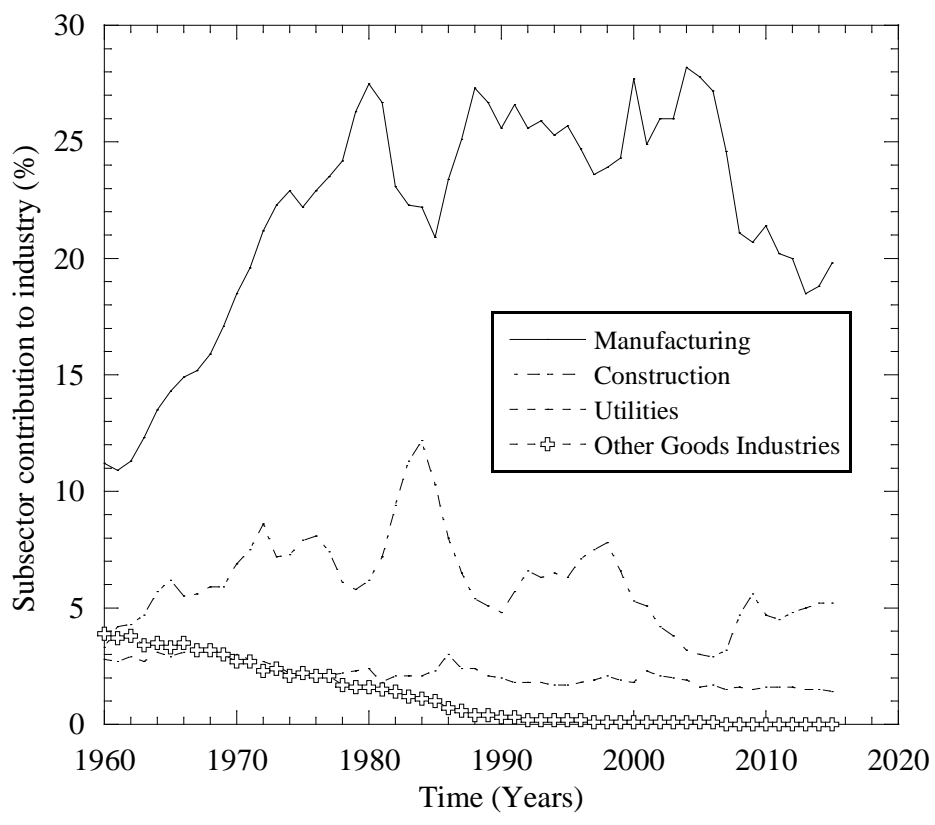

(b)

Figure 5. Singapore-(a) major sector contributions to GDP, (b) subsector contributions to the industrial sector [13].

Uganda's case, the service sector was making a significant contribution to GDP since 1960. But since the service sector employs mostly highly skilled personnel and does not offer a big number of jobs, the industrial sector was boosted to provide the needed employment and its contribution to GDP increased from $21.2 \%$ in 1960 to $37.8 \%$ in 20 years in 1980 . In the subsequent years, the industrial contribution to GDP was maintained at an average of about $34 \%$. 
From Figure 5(b), it can be noted that particularly, manufacturing was driving the industry's contribution to GDP. For the case of Uganda, Figure 2, it is construction that is making the biggest contribution to the industrial sector. Specifically for Singapore, the manufacturing subsector contribution to industry moved from $11.2 \%$ in 1960 to $27.5 \%$ in 20 years in 1980 . Though the subsector contribution slumped to a low of 20.9 in 1985, its average contribution to industrial growth was maintained at about $25 \%$ over the years. Manufacturing has a great potential of creating jobs, upgrading low price raw materials to high value commodities and advancing the use of technology in an economy.

Uganda's economy may be deemed to have been related to those of South Korea and Malaysia in the 1960s in a way that both had the agricultural sector and the service sector as the biggest contributors to GDP, Figure 6 and Figure 1. Industry was making a small contribution especially for the case of Uganda and South Korea. The percentage contributions of the major sectors to GDP over the years for the three countries are summarised in Table 2.

From Figure 1, Figure 6 and Table 2, important conclusions that led to the observed level of economic development seen today in the three countries can be made. First, it can be observed that all the three countries maintained and enhanced the level of service sector contribution to economic development over the years. It implies that the services that were required to support economic development were in place and enhanced over the years in the three countries.

Secondly, it can be noted that as Malaysia and South Korea moved out of the agrarian economy, they equally boosted their industrial sector to replace the vacuum that was being created by the declining agricultural sector. On the other hand, as Uganda's agricultural sector declined over the years, it industrial sector did not get the necessary boost to take up the vacuum that was being created in the economy as was the case for Malaysia and South Korea. This has not changed to date. This could probably be one of the reasons why Uganda's economy did not take off, and still hasn't, as those of its counterparts in East Asia.

Though Uganda's industrial sector contribution to GDP since 1990 to date was growing at a faster rate, 9.17\%, than that of Malaysia, 5.32\% and Singapore, $5.79 \%$, it never made any major impact to push the economy forward. This could probably be due to the fact that Uganda's industrial sector was driven by construction, Figure 2, rather than manufacturing, as was the case for Singapore, Malaysia and South Korea. Manufacturing causes a multiplier effect in the

Table 2. Contributions of the major sectors to GDP [6].

\begin{tabular}{ccccccccccccccc}
\hline & \multicolumn{3}{c}{ Agriculture (\%) } & \multicolumn{3}{c}{ Industry (\%) } & \multicolumn{4}{c}{ Services (\%) } \\
\hline & 1965 & 1980 & 2000 & 2015 & 1965 & 1980 & 2000 & 2015 & 1965 & 1980 & 2000 & 2015 \\
Uganda & 52.3 & 72.0 & 29.4 & 24.7 & 13.5 & 4.5 & 22.9 & 20.4 & 34.2 & 23.5 & 47.7 & 54.9 \\
Malaysia & 31.0 & 23.0 & 8.6 & 8.4 & 29.6 & 41.8 & 48.3 & 39.1 & 39.4 & 35.2 & 43.1 & 44.3 \\
South Korea & 39.4 & 15.1 & 4.4 & 2.3 & 21.3 & 34.2 & 38.1 & 37.9 & 39.3 & 50.7 & 57.5 & 59.7 \\
\hline
\end{tabular}




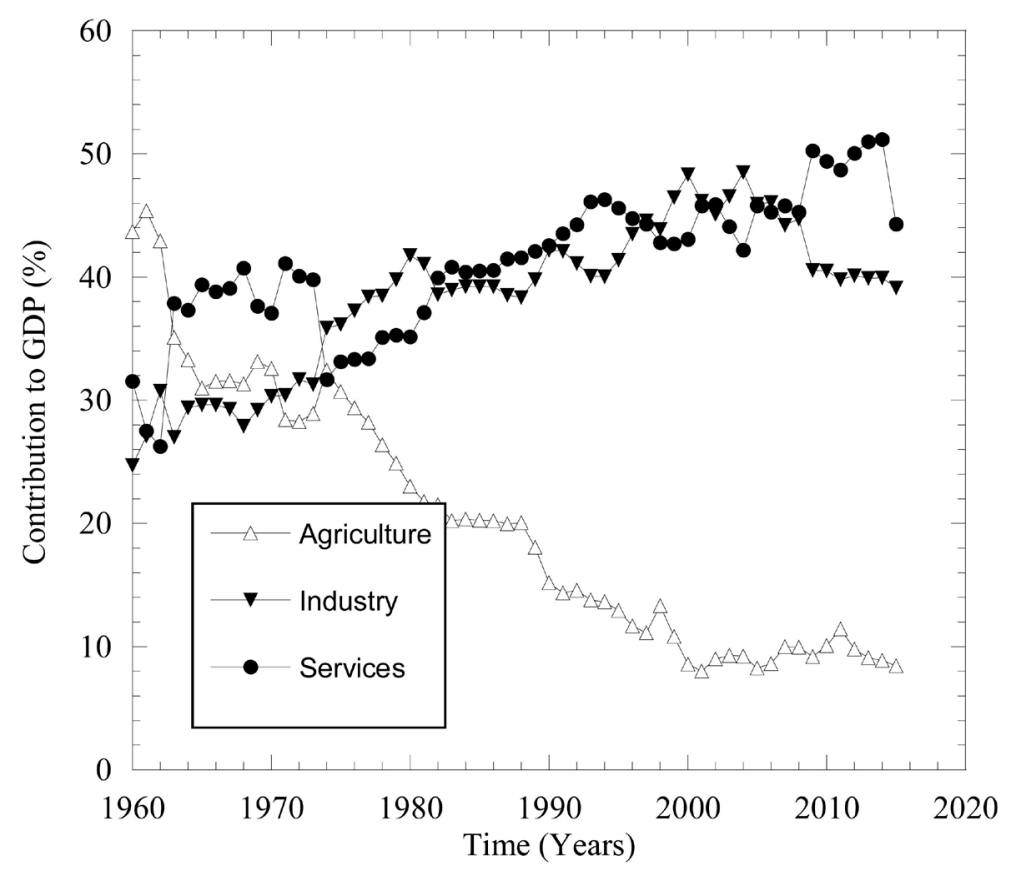

(a)

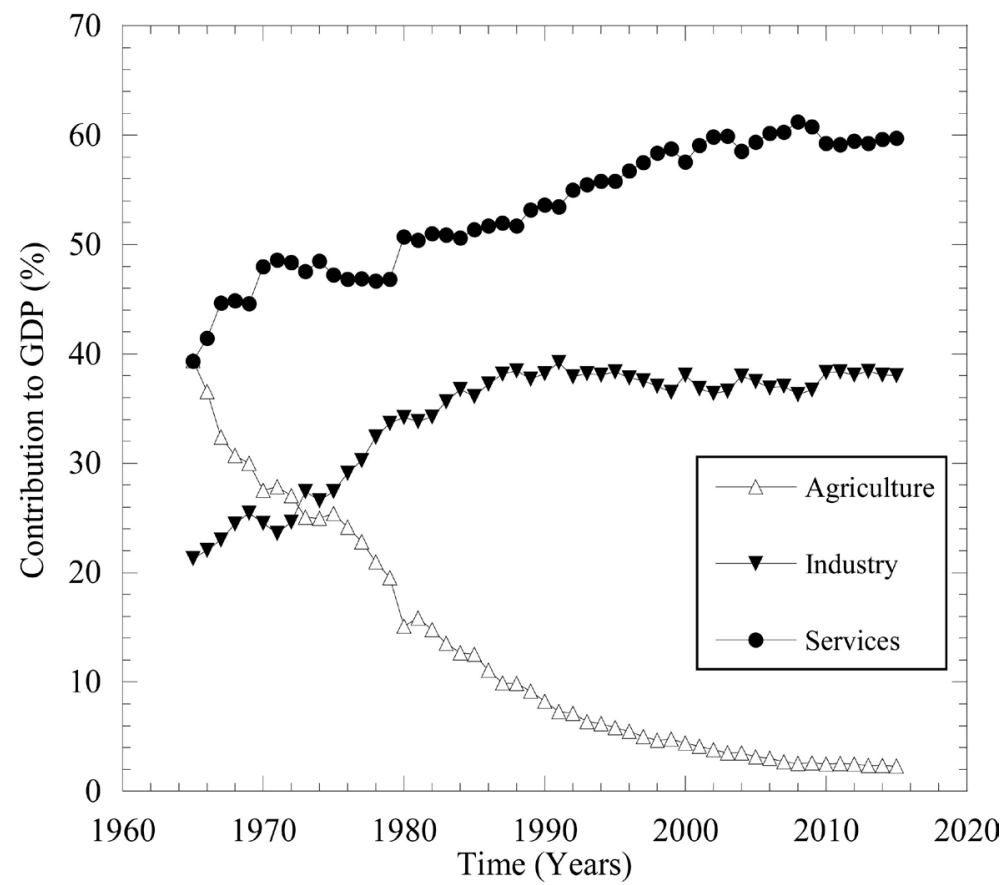

(b)

Figure 6. Major sector contributions to GDP, (a) Malaysia and (b) South Korea [6].

economy as it connects with other sectors and improves their productivity. Furthermore, jobs are created that improve the livelihoods of the people and increase the spending power.

Figure 7 shows the comparison of the manufacturing subsector contribution by percentage to GDP for the four countries.

It can be observed that the manufacturing subsectors of Singapore, Malaysia 


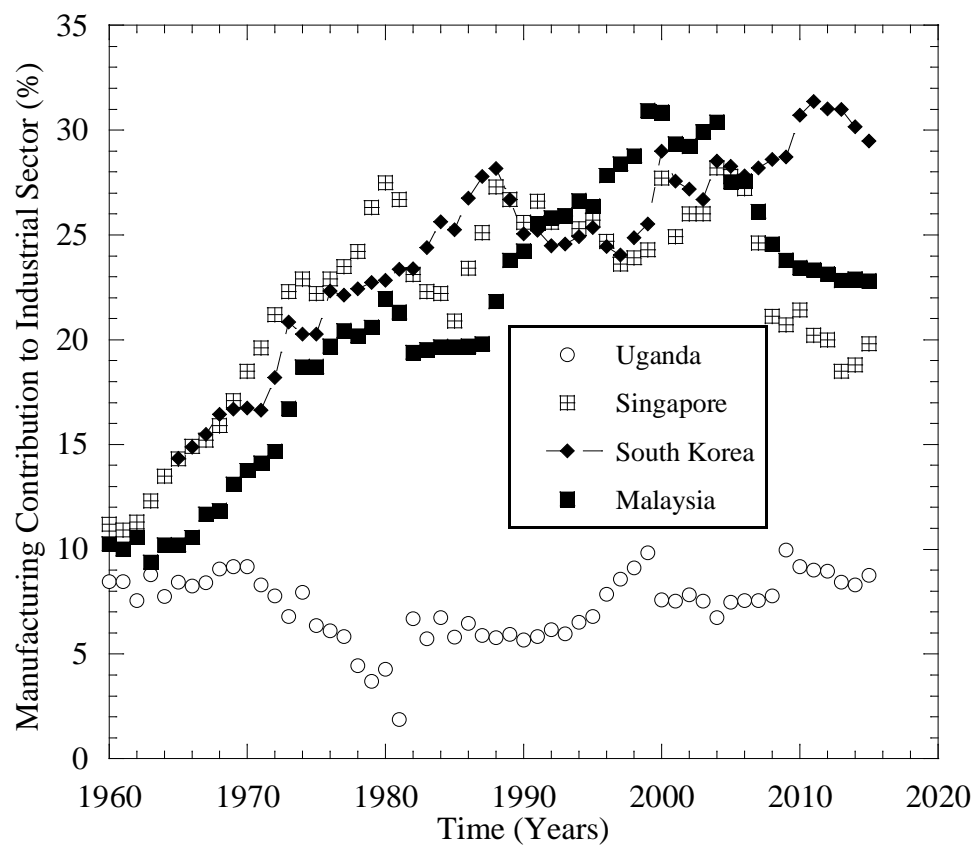

Figure 7. Manufacturing subsector contribution to industrial sector for Uganda, Malaysia, Singapore and South Korea [6].

and South Korea were boosted over the years to levels beyond 30\% contribution to industry but that of Uganda remained below $10 \%$ over the years.

Therefore, it can be noted that if Uganda is to require industrialisation to drive economic development towards achieving Vision 2040, there is a great need to boost the manufacturing sector so as to harness its numerous benefits; create linkages that will boost the other sectors especially agriculture that employees $70 \%$ of the population, turn the existing minerals into high value commodities and create the highly-needed employment. Currently, Uganda's manufacturing sector consists predominantly of last-stage (end-product) assembly and raw material processing, a high share of which is food processing [11]. All these are low value added activities and when it comes to export, such products are very sensitive to market price fluctuations which make forex earning very unpredictable. The country thus needs to move away from this pattern through boosting industrialisation.

\subsection{Interventions Employed by the East Asian Countries}

In order to achieve the economic growth that the East Asian countries realised through industrialisation, a number of strategic interventions were undertaken over a period of years. According to Pundy Pillay, 2010 [14], South Korea generally;

- Boosted the development of a vigorous, export-oriented manufacturing industry with a progressive shift towards high technology;

o $1 / 3$ (35\%) of the civilian labour force is employed in manufacturing

o $2 / 3(64 \%)$ are in the service sector 
- Has a current economic policy that favours a continued strong manufacturing sector with higher technological base, rather than a significant shift towards the service sector.

o Expansion of knowledge based industries,

o High and medium technology and knowledge intensive manufacturing

- Invested in education and raised a highly educated labour force. South Korea's abundant labour compensated for a lack of natural resources and allowed sustained industrial financing that, in turn, helped increase labour productivity and growth in the economy (Shin-Haing Kim, 2007) [15].

Specifically, South Korea introduced interventions and policies that drove industrial growth from one level to the next gradually, depending on the prevailing national conditions and needs, as highlighted in Table 3.

A Rostowian take-off of the Korean economy was possible through risk taking by the state led by President Chung-Hee Park, in collaboration with the early chaebol founders. Joint risk taking by the state and business connected to the credit supply, which was controlled by the government. From 1960 to 2004, an alternate sequence of financial repression and financial liberalisation occurred at approximately decadal intervals.

Successful growth performance to the state, entrepreneurs, a highly qualified workforce, and well-trained bureaucrats and firm managers were the factors that contributed to the transfer of technology and applications from contacts with foreign marketing personnel, engineers and scientists, and helped the market open. Acquisition of knowledge and know-hows through spill-over effects from imported capital goods and intermediates could be another factor which contributes for transfer of technology.

For the case of Singapore, the interventions taken at defined intervals are highlighted in Table 4.

Malasyia undertook steps that are highlighted in Table 5.

\subsection{Observations from the Applied Interventions}

Some general observations can be made from the interventions that were applied by the East Asian economies in their different stages of development:

1) At the on-set of the industrialisation drive, sequencing of industries was key; they concentrated on labour intensive, light manufacturing industries targeting the resources available to them, e.g. agricultural industries for Malaysia, in order to provide employment to their citizens;

2) They focused on educating their population, equipping them with skills that were directly related to boosting industrial development;

3) Focused on laying the ground for the establishment of heavy industries that were deemed to be backbone industries for industrialisation e.g. iron and steel industry, fertiliser factories for boosting agriculture;

4) As these countries moved from the agrarian economy, they equally invested in industrialisation to fill the gap that was being created in the economy by agricultural decline; 
5) They kept their service sector strong and invested in industry to enable it drive the economy; in industry, the manufacturing sub-sector was boosted to take the lead in driving economic development;

Table 3. Interventions used by South Korea over the years to facilitate industrialisation [14] [15].

\begin{tabular}{|c|c|}
\hline Period & Interventions \\
\hline $1960 \mathrm{~s}$ & $\begin{array}{l}\text { - Promotion of export and import-substitution industries; starting with subsistence agriculture (rice) and } \\
\text { labour-intensive, light manufacturing sectors (textiles, flour mills, breweries and bicycles) } \\
\text { - Technology obtained through foreign licensing and adapted for domestic production } \\
\text { o Vocational high schools-training in craft skills for the growing labour-intensive light industries. } \\
\text { o College admission quota was strictly regulated by the government-based on the analysis of the demand for } \\
\text { human resources } \\
\text { - } 2 \text { five year economic plans focused on establishing industries to supply basic industrial materials (establishing an } \\
\text { iron and steel company, oil company, fertiliser factory) } \\
\text { - Establishment of special purpose banks }\end{array}$ \\
\hline $1970 \mathrm{~s}$ & $\begin{array}{l}\text { - Industrial policy moved towards introducing heavy manufacturing industries (e.g. chemical and ship building) } \\
\text { - Introduced policies to further improve technological capabilities } \\
\text { o improved quality of technical and vocational training-supply technicians for the heavy and chemical industries } \\
\text { o higher education-the government selectively expanded the enrolment quotas in the fields of engineering, } \\
\text { natural sciences, business and commerce, and foreign languages } \\
\text { - More special purpose banks established }\end{array}$ \\
\hline $1980 \mathrm{~s}$ & $\begin{array}{l}\text { - Efforts to ensure a market-conducive environment by deregulating various sectors and liberalising trade and } \\
\text { financial markets } \\
\text { - Re-organisation of industries e.g. Hyundai was advised to make automobile manufacturing its core industry, } \\
\text { Samsung was told to concentrate on semiconductors, LG was directed to focus on petrochemicals and yield its } \\
\text { semiconductor business to Hyundai, the electrical generator business was assigned to Daewoo. } \\
\text { - Tight monetary and fiscal policies kept inflationary pressures under control } \\
\text { - Expanded higher education; investing in indigenous research and development-establishing a National Research } \\
\text { and Development Programme } \\
\text { o government abolished college entrance examinations and expanded educational opportunities for higher } \\
\text { education; renovating school facilities, introducing incentives for teachers }\end{array}$ \\
\hline $1990 \mathrm{~s}$ & $\begin{array}{l}\text { - Joined the Organisation for Economic Cooperation and Development (OECD) } \\
\text { - } \text { Economic deregulation and democratisation } \\
\text { - } \text { family-owned one) as was the case before } \\
\text { - Public investment in social overhead capital for schools, public libraries, and highway construction gradually } \\
\text { became more market based } \\
\text { - Pursued high value-added manufacturing by promoting indigenous high-technology innovation } \\
\text { - Government initiated diversification and specialisation of higher education institutions to accommodate the } \\
\text { diverse needs of society } \\
\text { - Financial market reforms } \\
\text { - Modern and accessible information infrastructure } \\
\text { o Harnessing the potential of science and technology; by } 2000,144 \text { major cities and regions were connected by } \\
\text { high-speed broadband networks through fibre-optic cables and by June } 2004,66 \% \text { of the population had access } \\
\text { to the internet } \\
\text { Expansion of research and development; created a knowledge-based economy } \\
\text { o R \& D expenditure increased from US } \$ 9 \text { million in } 1969 \text { ( } 73 \% \text { public) to US } \$ 24 \text { billion in } 2006 \text { ( } 75 \% \text { private). } \\
\text { o The number of researchers increased from } 5337 \text { in } 1969 \text { to } 256,598 \text { in } 2006 ; 7 \% \text { in government, } 26 \% \text { at } \\
\text { university and } 68 \% \text { in private sector. } \\
\text { o every university had a university-industry liaison office supported by government funds (promoting joint research) }\end{array}$ \\
\hline
\end{tabular}


Table 4. Interventions used by Singapore over the years to facilitate industrialisation [16] [17].

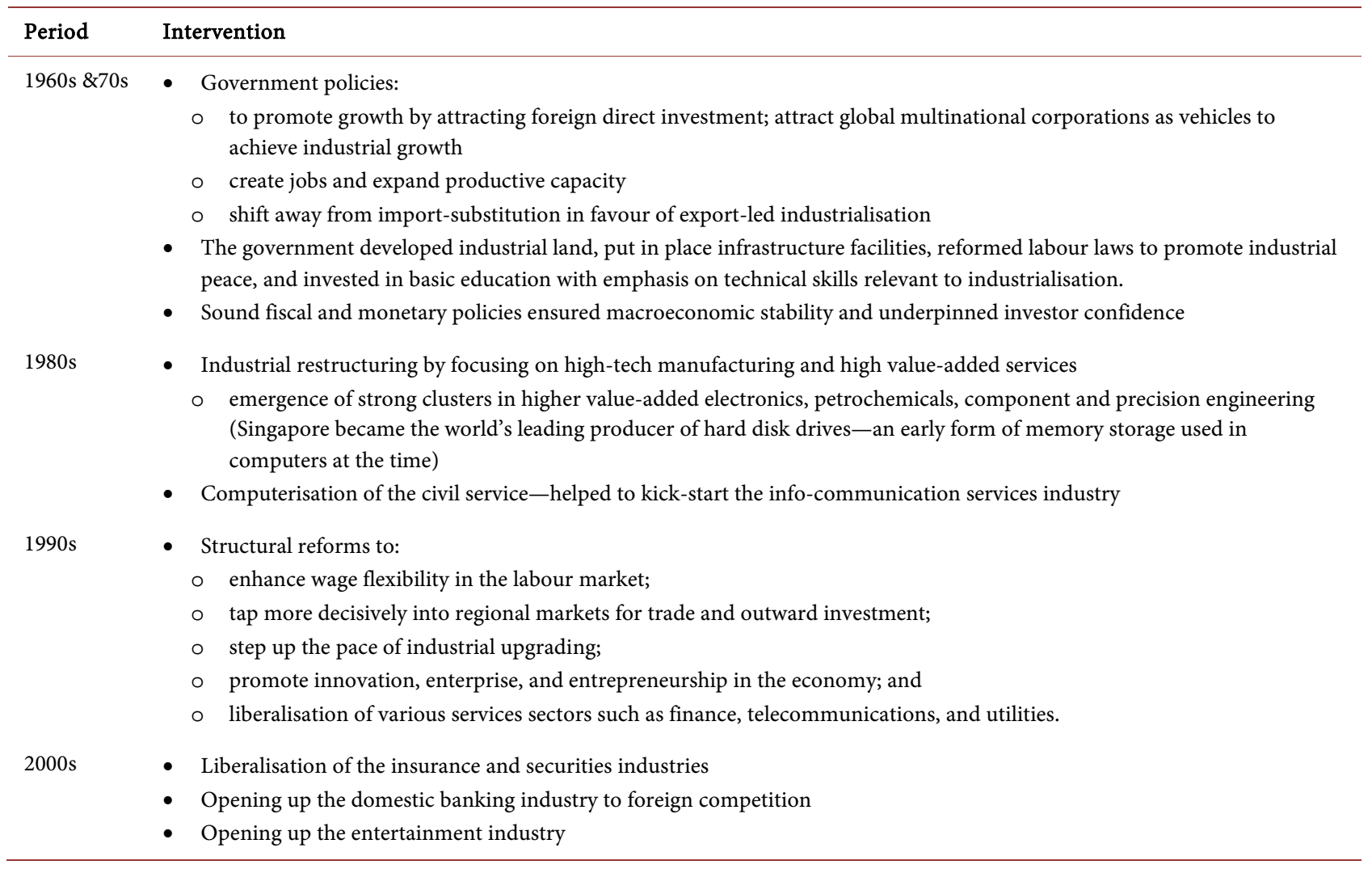

Table 5. Interventions used by Malaysia over the years to facilitate industrialisation [18] [19].

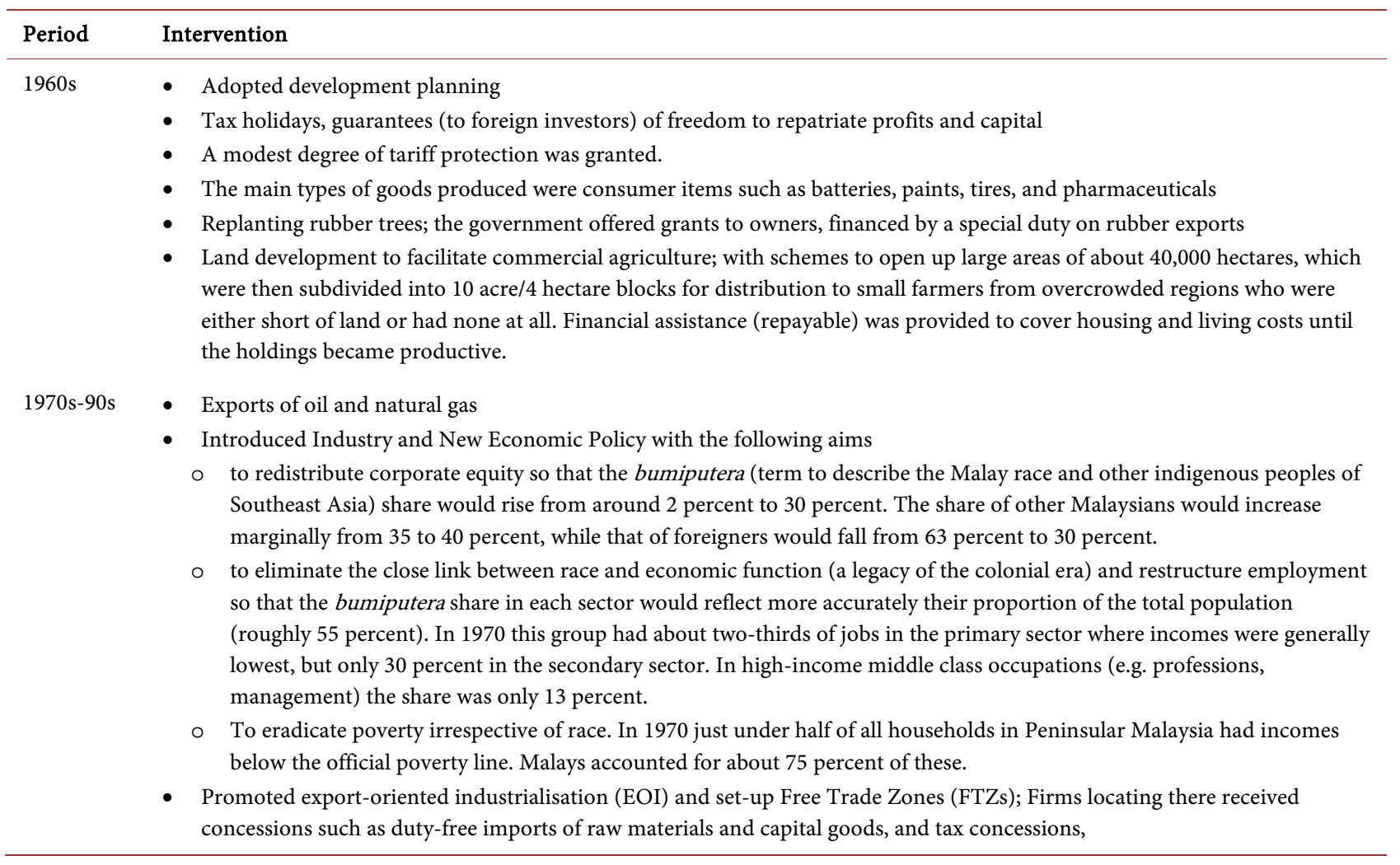


6) Imported capital goods and used them to develop technologies that could eventually produce them;

7) Imported technologies for industrial development and adapted them to suit their conditions and kept on improving on these to suit the changing trends of development (re-engineering);

8) Continuously improved their education system to supply the needed human resource at the various levels of economic development.

\section{Lessons for Uganda's Drive to Economic Development through Industrialisation}

As Uganda is driving towards becoming a middle-income country and eventually a developed economy using industrialisation as a vehicle, there is a need to focus interventions, priorities and sequence reforms in an integrated manner. Some lessons can be learnt from the East Asian countries, which can inform the country's next phase of interventions in boosting industrial development among which include:

1) Need to have policies and measures in place that support the growth of the existing manufacturing industries and the introduction of more light industries so as to provide employment to the existing labour force;

2) Introduce measures that support and boost agriculture and also light industries that process agricultural produce;

3) Lay a foundation for setting-up industries that serve as the foundation for the establishment of other industries e.g. the iron and steel industry, fertilisers industry for agriculture, among others;

4) Specify the skills that are needed at the various stages of industrialisation and inform the education system in terms of training technicians and professionals;

5) Plan for the establishment of incubation centres in different fields, science and technology parks so as to boost the area of innovation for introduction of new technologies that are tailored to the local specifications and needs and at the same time create more employment;

6) Identify the required infrastructural needs to support industrialisation and link these to the identified or set-up production zones in the country;

7) Strength the regional trade especially in products that Uganda has a comparative advantage e.g. agricultural produce and products;

8) Develop mechanisms that create and strengthen partnerships between research institutions and industry.

\section{Conclusion}

One of Uganda's biggest constraints to sustainable industrialisation has been the lack of a guided-step wise approach; spreading too wide and touching almost everywhere and generating less impact in view of the constraints. It's important to address this issue and also adopt an industrialisation agenda that will generate 
impact for the populace rather than push growth alone. As Uganda is driving towards becoming a middle-income country and eventually a developed economy using industrialisation as one of the avenues, there is need to focus interventions, priorities and sequence reforms in an integrated manner to boost the industrialisation agenda. There is need to present a practical pathway that will focus and sequence interventions in the industrial sector to guide its development so as to enable the sector make its contribution in transforming the economy. The country might need to consider formulating an Industrialisation Master Plan, which will harmonise the interventions and efforts of all stakeholders; private and public, to enable movement in one direction. This will help focus and target the industrialisation agenda of the country.

\section{References}

[1] Karl, T. (2017) ReviseSociology. Blog@WebPress.com. https://revisesociology.com/2017/03/17/industrialisation-and-development/

[2] Arkebe, O. (2015) Made in Africa: Industrial Policy in Ethiopia. Oxford University Press, Oxford.

[3] National Planning Authority (2013) Uganda Vision 2040. National Planning Authority, Kampala.

[4] Ministry of Tourism, Trade and Industry (2008) National Industrial Policy. Ministry of Trade, Tourism and Industry, Kampala.

[5] National Planning Authority (2015) Second National Development Plan (NDPII) 2015/16-2019/20. National Planning Authority, Kampala.

[6] World Bank (2016) DataBank: World Development Indicators. The World Bank. http://databank.worldbank.org/data/reports.aspx?source $=2 \&$ country=UGA

[7] Uganda Bureau of Statistics (2014) 2014 Statistical Abstract. Uganda Bureau of Statistics, Kampala.

[8] Ministry of Finance Planning and Economic Development (2015) Background to the Budget 2015/16 Fiscal Year: Maintaining Infrastructure Investment and Promoting Excellence in Public Service Delivery. Ministry of Finance Planning and Economic Development, Kampala.

[9] Bevan, D., Adam, C., Okidi, J. and Muhumuza, F. (2003) Poverty Eradication Action Plan Revision 2002/03: Discussion Paper on Economic Growth, Investment and Export Promotion. Ministry of Finance Planning and Economic Development, Kampala.

[10] Ssewanyana, S., Matovu, J.M. and Twimukye, E. (2011) Building in Growth in Uganda. In: Yes Africa Can: Success Stories from a Dynamic Continent, The World Bank, Washington, p. 492.

[11] The World Bank (2013) Uganda-About the Second Economic Update. The World Bank.

[12] African Development Bak Group (2014) East Africa’s Manufacturing Sector: Promoting Technology, Innovation. Productivity and Linkages. Africa Development Bank Group-Eastern Africa Regional Resource Centre (EARC), Nairobi.

[13] Ggoobi, R., Wabukala, B.M. and Ntayi, J. (2017) Economic Development and Industrial Policy in Uganda. Friedrich-Ebert-Stiftung, Kampala.

[14] Department of Statistics, Singapore (2015) M013911-Share of Nominal Gross 
Value Added by Industry, Annual Gross Domestic Product: National Accounts. http://www.tablebuilder.singstat.gov.sg/publicfacing/dataTable.action

[15] Pundy, P. (2010) Linking Higher Education and Economic Development: Implications for Africa from three Successful Systems. The Centre for Higher Education Transformation (CHET), Wynberg.

[16] Shin-Haing, K. (2007) Finance and Growth of the Korean Economy from 1960 to 2004. Seoul Journal of Economics, 20, 42.

[17] Khuong, M.V. (2011) Sources of Singapore's Economic Growth, 1965-2008: Trends, Patterns and Policy Implications. Lew Kuan Yew School of Public Policy, Singapore.

[18] Ravi, M. (2015) An Economic History of Singapore. Singapore Economic Review Conference, Singapore, August 2015, 11.

[19] Drabble, H.J. (2004) Economic History of Malaysia. EH.Net Encyclopedia, 31 July 2004. 